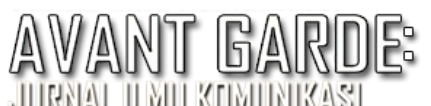

\title{
Pemanfaatan Teknologi Informasi Sebagai Media Pembelajaran Guru Dalam Pembelajaran Jarak Jauh Selama Pandemi
}

\author{
Oki Heryanto, Ute Lies Siti Khadijah, Ilham Gemiharto \\ Universitas Padjadjaran \\ Jl. Raya Bandung Sumedang KM.21, Kabupaten Sumedang, Indonesia \\ oki20001@mail.unpad.ac.id
}

Submitted: 21 Juni 2021, Revised: 27 September 2021, Accepted: 10 Oktober 2021

\begin{abstract}
Abstrak
Pembelajaran Jarak Jauh (PJJ) menjadi bentuk penerapan social distancing yang dilakukan agar setiap peserta didik mendapatkan haknya untuk tetap bisa belajar selama masa pandemi Covid-19. Pembelajaran Jarak Jauh (PJJ) memberikan layanan pendidikan tinggi kepada kelompok masyarakat yang tidak dapat mengikuti pendidikan secara tatap muka, dan memperluas akses serta mempermudah layanan pendidikan tinggi dalam pembelajaran. Sistem belajar yang dilakukan oleh murid dan guru melalui media pembelajaran dengan memanfaatkan teknologi informasi. Tujuan dalam penelitian ini adalah untuk mendeskripsikan pemanfaatan teknologi informasi sebagai media pembelajaran oleh para guru dan mengetahui keadaaan teknologi yang tersedia di sekolah sebagai alat pendukung pembelajaran jarak jauh. Penelitian ini menggunakan metode deskriptif kualitatif dengan pendekatan studi kasus. Pengumpulan data dilakukan dengan studi literatur dan wawancara kepada empat narasumber dari guru sekolah dasar negeri, sekolah menengah pertama negeri, dan sekolah menengah atas negeri yang berlokasi di kota Tulungagung, Jawa Timur. Kolaborasi siswa, guru, sekolah, orang tua, dan pemerintah menentukan keberhasilan PJJ, terutama untuk ketersediaan alat pendukung pembelajaran dan akses internet. Guru beradaptasi dan dituntut untuk berinovasi dalam memanfaatkan teknologi. Ada perubahan pemanfaatan teknologi untuk keberlangsungan pendidikan di Indonesia.
\end{abstract}

Kata kunci: Covid-19, guru, pendidikan jarak jauh, teknologi informasi

\section{Utilization of Information Technology as Teacher Learning Media in Distance Learning During the Pandemic}

\begin{abstract}
Distance Learning (PJJ) is a form of social distancing that is carried out so that every student has the right to continue to study during the Covid-19 pandemic. Distance Learning (PJJ) provides higher education services to community groups who cannot attend face-to-face education, and expands access and facilitates higher education services in learning. The learning system carried out by students and teachers through learning media by utilizing information technology. The purpose of this study was to describe the use of information technology as a medium of learning by teachers and to find out the state of technology available in schools as a means of supporting distance learning. This study uses a qualitative descriptive method with a case study approach. Data collection was carried out by studying literature and interviewing four resource persons from state elementary school teachers, junior high schools, and high schools located in the city of Tulungagung, East Java. The collaboration of students, teachers, schools, parents, and the government determines the success of PJJ, especially for the availability of learning support tools and internet access. Teachers adapt and are required to innovate in utilizing technology. There is a change in the use of technology for the sustainability of education in Indonesia.
\end{abstract}

Keywords: Covid-19, teacher, distance education, information technology 


\section{PENDAHULUAN}

Covid-19 (Corona Virus Disease-2019), merupakan virus baru yang menular disebabkan oleh virus korona. Orang yang kontak langsung dengan pasien Covid-19 sangat berisiko tertular (covid19.go.id, 2021). Untuk mencegah penularan virus Covid-19 salah satunya adalah menjaga jarak dengan orang lain, menghindari dan tetap di rumah (WHO, 2021). Kasus Covid-19 berlangsung cepat dan sudah menyebar antar negara. Hingga saat ini, sudah satu tahun lebih virus Covid-19 terus menyebar ke seluruh Indonesia. Update perkembangan kasus harian Covid-19 per 28 Maret 2021, jumlah kasus aktif mencapai 124.236 dan jumlah kasus meninggal sebanyak 40.449. Covid-19 tidak hanya menyerang pada orang dewasa, tapi juga bisa menular ke anak-anak (covid19.go.id, 2021).

Dalam menangani pandemi Covid-19, pemerintah mengeluarkan berbagi kebijakan salah satunya kebijakan di bidang pendidikan selama masa pandemi, yaitu Pencegahan dan Penanganan Covid-19 di Kementerian Pendidikan dan Kebudayaan tertera pada SE Mendikbud No. 2/2020, Protokol pencegahan Covid-19 pada satuan pendidikan yang tertera pada SE Mendikbud No. 3/2020), Kebijakan Pendidikan Selama Masa Darurat Covid-19 pada SE Mendikbud 4/2020 dan Pembelajaran secara daring dan bekerja dari rumah yang tertera pada Surat Mendikbud No. 36962/MPK.A/HK/2020. Pemerintah juga mendukung pendidikan Indonesia di masa pandemi dengan menetapkan dana untuk pendidikan 20 persen dari anggaran pendapatan dan belanja negara (APBN) atau daerah (APBD). Tidak ada pemotongan anggaran pendidikan, karena dunia pendidikan merupakan fondasi pembangunan sumber daya manusia (SDM) setiap bangsa. Anggaran pendidikan Indonesia mengalami kenaikan Rp140 triliun dalam empat tahun terakhir. Saat ini, anggaran pendidikan sekitar Rp508 triliun (Sindonews, 2020).

Kebijakan Pembatasan Sosial Berskala Besar (PSBB) dalam penanganan Covid-19 diharapkan bisa memutus rantai penularan dan penyebaran wabah Covid-19 di klaster sekolah-sekolah. Dengan Pembelajaran Jarak Jauh (PJJ) selain salah satu bentuk penerapan social distancing, siswa juga tetap bisa belajar dengan memanfaatkan media komunikasi berbasis teknologi (kemdikbud, 2020). Teknologi dalam PJJ bisa disesuaikan dengan kebutuhan pengguna, seperti yang diungkapkan Wiebe Bijker dan Trevor Pinch (1984) bahwa teknologi yang hadir di tengah masyarakat menjadi dampak bukan sebagai penentu. Pendekatan ini sesuai dengan pendekatan teori SCOT (Social Construction of Technology), bahwa perkembangan teknologi merupakan bentuk lain dari konstruksi sosial.

Menurut Baalen, Fenema, \& Loebbecke (2016), dalam teori SCOT terdapat empat dimensi, yaitu teknologi, interaksi, kelompok sosial dan konteks. Dalam perkembangan teknologi digital, bermula dari informasi organisasi. Seperti halnya dengan interaksi interpersonal, tidak hanya hubungan antar manusia, melainkan manusia - teknologi, atau hubungan antar teknologi. Kemudian kelompok sosial dalam masyarakat pun membentuk jejaring-jejaring dalam konteks sosio digital. Hal ini berkaitan dengan konsep PJJ dalam pandangan masyarakat bahwa ilmu pengetahuan dan teknologi dikonstruksi secara sosial

Penelitian Pembelajaran Jarak Jauh (PJJ) selama Covid-19 telah banyak dilakukan peneliti sebelumnya. Nuriana, I., \& Adelina, F. (2021) melakukan penelitian dari sudut pandang persepsi orang tua terhadap PJJ, dengan sampling orang tua siswa sekolah dasar di 
Desa Tanggung, Kecamatan Campurdarat, Tulungagung. Untuk tingkat Sekolah Dasar, tidak hanya siswa tapi orang tua juga dituntut untuk beradaptasi dengan metode PJJ. Pembelajaran jarak jauh tidak memiliki persepsi negatif bagi orang tua, namun memberikan beban bagi orang tua atau keluarga, baik secara fisik maupun mental. Ketika pembelajaran dilakukan dengan tatap muka, orang tua sepenuhnya menyerahkan kepada guru. Berbeda dengan PJJ untuk tingkat sekolah dasar, siswa membutuhkan pendampingan orang tua.

Penelitian pembelajaran daring tingkat SMA di Tulungagung, dilakukan oleh Maghfirani, R.T, \& Hariastuti, R.T. (2021) tentang hubungan antara penyesuaian diri PJJ dengan burnout pada siswa saat pandemi Covid-19. Hasil penelitian menunjukkan kontribusi penyesuaian diri pembelajaran daring terhadap burnout pada siswa SMA di Kabupaten Tulungagung sebesar $17,9 \%$. Jika siswa berhasil menyesuaikan diri dengan pembelajaran daring, maka semakin rendah siswa mengalami burnout. Sehingga diperlukan peran guru saat mengajar untuk menggunakan media visual yang menarik agar siswa tidak bosan dan mengurangi resiko burnout.

Berdasarkan uraian pada latar belakang, maka tujuan dalam penelitian ini adalah untuk mendeskripsikan pemanfaatan teknolgi informasi sebagai media pembelajaran oleh para guru yang menerapkan PJJ selama masa pandemi. Sebuah metode yang pada pelaksanaanya tidak bertatap muka secara langsung dalam pembelajaran dan membutuhkan kolaborasi dengan peran teknologi dan dukungan sektor pemerintah. PJJ tidak akan berhasil tanpa adanya teknologi yang memfasilitasi media pembelajaran. Pembelajaran biasanya menggunakan media berbasis internet. Contohnya adalah video animasi, youtube, google classroom, whatsapp dan lain sebagainya (Rahmawati, 2016). Penelitian ini juga bertujuan untuk mengetahui sejauh mana guru menjalin komunikasi dengan siswa dan orang tua selain menguasai tantangan mengajar dalam sistem berbasis internet, menyediakan pelajaran secara online, memperkenalkan konten dengan metode pembelajaran baru, memberikan diferensiasi tugas, menciptakan komunikasi dua arah dalam pertemuan virtual dan melakukan penilaian online. Kompetensi guru dalam menguasai tantangan penggunaan sistem berbasis internet menjadi sangat krusial.

Dalam peran TIK, penelitian ini bertujuan untuk mengetahui keadaaan teknologi yang tersedia di sekolah sebagai alat pendukung pembelajaran jarak jauh, pengetahuan penggunaan media pembelajaran berbasis internet sebagai inovasi untuk mengimbangi kompetensi digital. Dan keterkaitan peran media sebagai salah satu model pentahelix yang bersinergi dengan pemerintah untuk mendukung sistem PJJ selama pandemi Covid-19.

\section{METODE PENELITIAN}

Penelitian ini menggunakan metode deskriptif kualitatif dengan pendekatan studi kasus. Menurut Sugiyono (2017:29) mengungkapkan bahwa penelitian deskriptif dilakukan untuk mengetahui keberadaan variabel mandiri, baik hanya pada satu variabel atau lebih (variabel yang berdiri sendiri atau variabel bebas) tanpa membuat perbandingan variabel itu sendiri dan mencari hubungan dengan variabel lain. Dalam penelitian ini, pengumpulan data dilakukan dengan studi literatur dan wawancara dalam kurun waktu Maret-Mei 2021. Narasumber dalam pengumpulan data-data terkait pembelajaran jarak jauh adalah tiga guru sekolah negeri yang berlokasi di kota Tulungagung, Jawa Timur. Diantaranya, yaitu: (1) Ibu 
Kristin Wijayanti, guru SDN 1 Tertek Tulungagung, wawancara ini bertujuan untuk mendapatkan penggambaran pembelajaran jarak jauh dari perspektif guru tingkat dasar. (2) Ibu Anik Purwani, guru SMP Negeri 1 Tulungagung, wawancara ini bertujuan untuk mendapatkan penggambaran pembelajaran jarak jauh dari perspektif guru tingkat menengah pertama. (3) Ibu Citra Devi, guru SMA Negeri Kauman, Tulungagung, dan (4) Bapak Titis Eswindro, guru SMA Negeri 1 Kedungwaru, wawancara ini bertujuan untuk mendapatkan penggambaran pembelajaran jarak jauh dari perspektif guru tingkat menengah atas.

\section{HASIL DAN PEMBAHASAN}

\section{Teknologi Informasi dan Komunikasi (TIK)}

Dalam bidang pendidikan, keberadaan Information and Communication Technology (ICT) atau yang lebih dikenal dengan TIK sangat penting karena sebagai penunjang utama bagi pembangunan sektor pendidikan yang semakin kompleks. Maka diperlukan suatu media yang dapat memberikan inovasi dan menyelesaikan segala permasalahan pendidikan (khususnya dalam kegiatan mengajar). TIK adalah istilah yang luas dan mencakup semua peralatan teknis baik digunakan untuk memproses dan mengkomunikasikan informasi. TIK mencakup dua aspek yaitu teknologi informasi dan teknologi komunikasi. Teknologi informasi mencakup semua hal yang berkaitan dengan proses, penggunaan sebagai alat, manipulasi, dan pengelolaan informasi. Pada saat yang sama, teknologi komunikasi terkait dengan penggunaan alat untuk memproses data dan mentransfer data dari satu perangkat ke perangkat lainnya. Oleh karena itu, teknologi informasi dan teknologi komunikasi merupakan dua konsep yang tidak dapat dipisahkan.

TIK merupakan suatu sistem atau teknologi yang dapat mengurangi batasan ruang dan waktu untuk mengambil, memindahkan, menganalisis, menyajikan, menyimpan, dan mengubah informasi data menjadi informasi. Dalam hal pembelajaran, TIK mencakup segala hal yang berkaitan dengan penggunaan komputer untuk mengolah informasi dan sebagai alat bantu belajar serta sebagai sumber informasi bagi guru dan siswa.

\section{Pembelajaran Jarak Jauh}

Menurut Moore (1983) konsep dari pembelajaran jarak jauh adalah tidak bertatap langsung atau adanya keterpisahan. Baik terpisah jarak (fisik) antara tenaga pendidik dan yang dididik, dan terpisah komunikasi (psikologi) diantara keduanya. Dalam konsep keterpisahan diperlukan jembatan untuk menyamakan persepsi sehingga pembelajaran berjalan efektif. Untuk mengatasi hal tersebut, adanya keterpisahan atau jarak transaksi antara guru dan siswa melalui penggunaan media pembelajaran yang dirancang sedemikian rupa agar dapat melakukan pembelajaran kepada peserta belajar dengan bantuan yang relatif sedikit dari guru untuk menyajikan rangkaian materi pembelajaran. Bahan belajar harus mampu mengupayakan tercapainya sasaran kompetensi yang diharapkan. Menurut Rustam Sehar dan Paulina Pannen (2004) bahan belajar harus berisi tujuan instruksional, uraian materi yang berisi konsep, prinsip dan prosedur, contoh dan non contoh, latihan, rangkuman, tes formatif, umpan balik, referensi dan kunci jawaban tes formatif.

Teknologi pembelajaran berbasis internet di dunia pendidikan telah berkembang pesat, terbuka, fleksibel, dan bisa dilakukan dengan metode jarak jauh tanpa harus bertatap 
muka langsung. Sejalan dengan perkembangan teknologi, perlu dilakukan upaya untuk memenuhi kebutuhan pembelajaran yang beragam dengan meningkatkan kemampuan untuk mengimbangi keberagaman metode. Sementara itu banyak yang berpikir bahwa lingkungan online pada dasarnya lebih akomodatif terhadap keberagaman, Barbour dan Reeves (2009) mengemukakan bahwa faktor yang banyak membuat seorang siswa berhasil menggunakan teknologi pembelajaran sering dikaitkan dengan keadaan sosial ekonomi. Selain hal tersebut, pandemi Covid-19 saat ini telah mengajarkan transisi atau pergantian secara halus dengan mengandalkan pembelajaran jarak jauh dengan sistem online. Internet adalah cara yang paling efektif untuk berkomunikasi antara siswa dan guru, walau diantara mereka banyak yang mengalami kesedihan dan stress karena tidak bisa bertatap langsung dan hanya bisa mengandalkan internet. Kebanyakan dari sekolah-sekolah menganggap hal ini bukan sebagai PJJ melainkan menjadi suatu keringanan sistem pembelajaran dalam keadaan darurat karena Covid-19 (Hodges, dkk, 2020).

Bahkan ketika siswa dapat mengakses internet, masih ada tantangan yang beragam dari para siswa ketika mencoba untuk belajar. Layne, dkk (2013) membuat penelitian untuk membangun teori seputar retention and engagement dengan melibatkan adult online learner membuat profil yang berisi jenis kelamin, usia, suku, dan variabel sosial ekonomi. Hasilnya teridentifikasi melek komputer dan keterampilan navigasi, kemampuan koneksi elektronik, dan perasaan terisolasi sebagai penghalang keberhasilan. Dan dalam penelitian lain, Xu dan Jaggars (2014) menemukan bahwa siswa yang berusia lebih muda, berjenis kelamin laki-laki, dan berasal dari latar belakang minoritas cenderung tidak berhasil penyesuaian untuk belajar dari jarak jauh dengan teknologi pembelajaran berbasis internet. Peran komunikasi guru tentunya menjadi sangat penting pembelajaran jarak jauh.

PJJ merupakan bidang pendidikan yang berfokus pada penggunaan teknologi dalam penyampaian kurikulum kepada siswa yang tidak secara fisik berada di lokasi untuk menerima pendidikannya (Taylor, 2006). Pengajaran dan pembelajaran jarak jauh dapat disampaikan melalui pembelajaran elektronik penuh atau dikenal sebagai program mode pengiriman tunggal (sinkron atau asinkron) atau program mode pengiriman campuran (Singh, 2003). Kemajuan teknologi dan internet telah membuat media belajar mengajar lebih interaktif dan dinamis dari jarak jauh (Khan, 2005; Swerling \& Thorson, 2014). Komunikasi memegang peranan yang sangat penting dalam keberhasilan program pendidikan jarak jauh. Guffey (2008) mendefinisikan komunikasi sebagai proses di mana pengirim memiliki ide, mengkodekannya sebagai pesan, dan mengirimkannya melalui saluran (tatap muka, email, telepon, atau metode transmisi lainnya). Penerima kemudian menerjemahkan pesan ini (Guffey, 2008). Definisi ini jelas menunjukkan hubungan antara 'belajar-mengajar' dan 'komunikasi,' karena guru terus-menerus memberikan pengetahuan baru (atau mengirimkan informasi) dan siswa menerima pengetahuan ini. Kebutuhan untuk memperluas pendidikan melalui pembelajaran jarak jauh dinyatakan dalam rencana bahwa siswa akan mendapatkan keuntungan dari infrastruktur dunia maya yang kuat yang dapat mendukung penggunaan teknologi seperti konferensi video, streaming langsung, dan terbuka besar-besaran. Institusi pendidikan tinggi juga akan diminta untuk memastikan bahwa $70 \%$ program mereka menggunakan model pembelajaran campuran. 
Ironisnya, dukungan instruksional dalam program pendidikan jarak jauh belum diletakkan dalam perspektif yang tepat (Mei, Su Ahmad, \& Rosnain, 2017). Hal ini terjadi karena sebagian besar institusi belum sepenuhnya menganut pendidikan jarak jauh (Sa'adon, Dahlan, \& Zainal, 2013). Institusi semacam itu menawarkan pembelajaran jarak jauh sebagai program yang dibuat. Dalam pengaturan ini, persepsinya adalah bahwa peran instruktur terutama untuk menilai atau menandai tugas siswa, yang diselesaikan pada waktu yang ditentukan (Lentell, 2003). Karena kebutuhan akan materi berkualitas yang dapat meningkatkan keterlibatan kognitif siswa dalam pendidikan jarak jauh menjadi keharusan, instruktur pembelajaran jarak jauh harus memperoleh pengalaman yang diperlukan dalam pembelajaran jarak jauh (Sa'adon, Dahlan, \& Zainal, 2013; Rajasegeran, 2012).

Banyak teori dikemukakan untuk memberi penjelasan mengenai karakteristik PJJ. Meskipun saling berbeda pada beberapa detil, ada semacam kesepakatan mengenai karakteristik PJJ adalah keterpisahan antara pengajar (guru) dan pelajar (siswa), dan ini menjadi landasan utama pemikiran mengenai asal muasal perkembangan teori dan strategi penyelenggaraan PJJ. Dua upaya yang menjadi tumpuan untuk mencermati bidang studi ini adalah pengembangan teori dan pendekatan sistematik risetnya. Moore menyetakan bahwa meskipun PJJ pada dasarnya adalah pendidikan, dan karenanya kita dapat menerapkan teori dan praktik pendidikan konvensional, dampak adanya jarak transaksional menjadikan diperlukannya pemikiran dan praksis yang tidak biasa. Jarak transaksional merupakan fungsi dari dua variabel, yakni dialog dan struktur. Dialog menjelaskan tentang sejauh mana, dalam program pendidikan, pembelajar, program, dan pengajar mampu saling merespon satu sama lain (Moore, 1983:57). Sebagai contoh, program pendidikan yang hanya memberikan bahan ajar tercetak kepada pembelajar, tidak akan menghasilkan dialog. Program pendidikan korespondensi yang memberikan umpan balik atau komentar atas tugas secara tertulis, dalam batas tertentu menyediakan dialog (tertulis). Program yang mengkombinasikan korespondensi dan telekonferensi lebih bersifat dialogis.

PJJ pada dasarnya adalah pendidikan, karena kita dapat menerapkan teori dan praktik pendidikan tradisional, dan dampak dari jarak transaksi memerlukan pemikiran dan praktik yang tidak konvensional. Jarak transaksi merupakan fungsi dari dua variabel yaitu dialog dan struktur. Dialog menjelaskan sejauh mana peserta didik, dan guru dapat menanggapi satu sama lain dalam sebuah program pendidikan (Moore, 1983: 57). Misalnya, program pendidikan yang hanya memberikan materi cetak kepada peserta didik tidak akan menghasilkan dialog. Program pendidikan korespondensi yang memberikan umpan balik atau komentar tentang tugas dalam bentuk tertulis memberikan dialog (tertulis) sampai batas tertentu. Program yang menggabungkan komunikasi dan telekonferensi ini lebih bersifat percakapan.

Garrison (2003) juga menyatakan tiga karakteristik untuk mendefinisikan pembelajaran jarak jauh sebagai berikut ini: (1) Pendidikan jarak jauh mengandung arti bahwa sebagian besar komunikasi antar pendidikan seorang guru dan muridnya muncul secara tidak bersebelahan (2) Pendidikan jarak jauh harus melibatkan komunikasi dua arah antara (antar) guru dan siswanya untuk memfasilitasi dan mendukung proses pendidikan. (3) Pendidikan jarak jauh menggunakan teknologi untuk menengahi komunikasi dua arah yang dibutuhkan. Pembelajaran jarak jauh memberikan situasi yang jauh lebih baik bagi siswa 
daripada pembelajaran tradisional karena pembelajaran dapat terjadi dimana saja dan kapan saja di luar sekolah. Pembelajaran jarak jauh mempersiapkan jalan untuk sebagian besar tujuan pendidikan seperti mandiri untuk belajar, belajar di setiap tempat dan tidak tergantung pada waktu tertentu, partisipasi pembelajaran dan pendidikan, penilaian diri dan penyajian respon yang cepat dari penelitian sebelumnya. Efektivitas dapat dianggap sebagai kepuasan pelajar dalam pembelajaran jarak jauh. Proses pembelajaran yang efektif adalah yang berkelanjutan dan tidak hanya terjadi satu kali. Boettcher (2007) mengatakan bahwa perencanaan lingkungan belajar yang efektif membutuhkan konsepsi dan pemahaman tentang prosedur mental terkait dengan psikologi, pengetahuan dan prinsip pedagogik (seni atau ilmu bagaimana menjadi seorang guru, dalam hal ini sangat berkaitan erat dengan pengajaran), dan teori pembelajaran dasar yang menentukan efektivitas penilaiannya.

\section{Pemanfaatan Teknologi Sebagai Media Pembelajaran}

Seperti di negara-negara lain sebagai imbas lockdown dari pandemi Covid-19, ratusan ribu sekolah di Indonesia ditutup pada Maret 2020. Menurut data kemdikbud (2020) sebanyak 534.630 satuan pendidikan menerapkan pembelajaran jarak jauh. Sedangkan jumlah tenaga pengajar baik guru atau dosen yang menerapkan pembelajaran jarak jauh totalnya mencapai 4.183.591 guru. Jumlah paling banyak adalah tingkat SD/MI/Sederajat sebanyak 1.702.377 guru. Dan untuk jumlah siswa yang menerapkan belajar dari rumah total sebanyak 68.729.037 siswa. Akibatnya, guru menghadapi tantangan yang signifikan dan harus beradaptasi dengan pengajaran online, dan tetap mempertahankan komunikasi dengan para siswa untuk mendukung pembelajaran dan pengembangan siswa. Namun, sejauh mana keberhasilan guru dalam menguasai pembelajaran online masih menjadi tantangan.

Penutupan sekolah yang terjadi hingga saai ini membentuk percepatan transformasi dalam inovasi teknologi dan digitalisasi, tidak terkecuali di bidang pendidikan. Akibatnya, digitalisasi di sekolah telah menjadi masalah yang menonjol, terlepas dari dan sebelum pandemi Covid-19 (König dkk, 2020). Namun, di Indonesia masih banyak sekolah yang tertinggal sehubungan dengan TIK. Karena hal tersebut lalu timbul pertanyaan dalam kondisi masa pandemi seperti ini apakah mereka mampu mengikuti pembelajaran online dan menggunakan alat digital. Lalu bagaimana dengan guru dalam menghadapi kompetensi dan penguasaan sistem yang serba digital.

Lockdown sekolah yang sedang dihadapi oleh guru, siswa, dan orang tua merupakan situasi baru ya ng belum pernah dialami sebelumnya (Huber dan Helm 2020). Pengajaran dan pembelajaran di sekolah hanya bisa dilalui dengan cara alternatif. Guru harus beralih ke pengajaran online, mengharuskan mereka menggunakan berbagai alat digital untuk memecahkan masalah dan menerapkan pendekatan baru proses mengajar dan belajar (Eickelmann dan Gerick 2020). Di luar tujuan instruksional, para guru juga diharuskan untuk menjaga kontak dengan siswa mereka untuk menjelaskan integrasi sosial dari kelompok belajar mereka. Kurikulum sekolah pun harus ditingkatkan dan disesuaikan dengan TIK, dan siswa harus diberi kesempatan untuk menggunakan alat digital untuk pemecahan masalah yang kreatif dan inovatif (Kozma 2011, 115). 
Tabel 1 Media Pembelajaran dan Inovasi Guru dalam PJJ Selama Covid-19

\begin{tabular}{|l|l|l|}
\hline \multicolumn{1}{|c|}{ Nama Sekolah } & \multicolumn{1}{|c|}{ Media Pembelajaran } & \multicolumn{1}{c|}{ Inovasi Guru } \\
\hline SD Negeri Kauman & $\begin{array}{l}\text { Memberikan tugas melalui } \\
\text { whatsapp group kelas dan } \\
\text { video pembelajaran di } \\
\text { youtube. }\end{array}$ & $\begin{array}{l}\text { Membuat bahan ajar video yang } \\
\text { menarik dan mudah dicerna siswa }\end{array}$ \\
\hline $\begin{array}{l}\text { SMP Negeri 1 } \\
\text { Tulungagung }\end{array}$ & $\begin{array}{l}\text { Menggunakan google } \\
\text { classroom, video conference } \\
\text { dengan google meet, dan } \\
\text { video pembelajaran di } \\
\text { youtube. }\end{array}$ & $\begin{array}{l}\text { Membuat bahan ajar video yang } \\
\text { menarik dan mudah dicerna siswa. }\end{array}$ \\
\hline $\begin{array}{l}\text { SMA Negeri 1 } \\
\text { Kedungwaru }\end{array}$ & $\begin{array}{l}\text { LMS moodle, unit kegiatan } \\
\text { belajar mandiri, video } \\
\text { pembelajaran yg diunggah di } \\
\text { youtube, media diskusi } \\
\text { melalui google class room dan } \\
\text { whatsapp group, pembelajaran } \\
\text { melalui zoom dan google } \\
\text { meet. }\end{array}$ & $\begin{array}{l}\text { Pembelaran melalui zoom } \\
\text { (pembelajaran langsung) dan membuat } \\
\text { video pembelajaran untuk diunggah di } \\
\text { dengan agar dapat dibuka siswa } \\
\text { (pembelajaran tidak langsung) }\end{array}$ \\
\hline SMA Negeri 1 Kauman & $\begin{array}{l}\text { Menggunakan google } \\
\text { classroom, whatsapp group } \\
\text { kelas, dan video pembelajaran } \\
\text { di youtube. }\end{array}$ & $\begin{array}{l}\text { Membuat bahan ajar berupa slide } \\
\text { presentasi dan video yang menarik dan } \\
\text { mudah dicerna siswa }\end{array}$ \\
\hline
\end{tabular}

Sumber: Data diolah peneliti (2021)

Dalam wawancara kepada salah satu guru SD Negeri bernama Ibu Kristin, menjelaskan bahwa peran orang tua dan alat komunikasi sangat penting. Ibu Kristin mengajar 25 siswa dengan latar belakang ekonomi menengah ke bawah. Memang, para siswa memiliki HP semua tapi milik orang tua, dalam arti para siswa tidak memiliki HP sendiri. Kendalanya ketika orang tua bekerja pagi sampe sore dan HP dibawa orang tua, sehingga anak tidak bisa mengikuti pembelajaran online. Selain itu, kuota internet juga sering menjadi masalah tapi bisa teratasi dengan bantuan kuota internet dari pemerintah. Kendala lain adalah guru harus membuat video pembelajaran yang mudah dipahami siswa. Ibu Kristin juga harus mengambil gambar atau video dan belajar editing video yang sebelumnya belum pernah dilakukannya. Ibu Kristin mengaku lebih mudah menjelaskan langsung tanpa harus repot membuat video terlebih dahulu.

Kendala yang ditemui Ibu Kristin pun berlanjut, setelah mengirimkan video pembelajaran via group whatsapp para siswa masih mengeluh kapasitas HP terbatas atau memory full sehingga video tidak bisa diunduh. Lalu Ibu Kristin mengupload di youtube supaya tidak perlu mengunduh video. Beberapa siswa pun masih mengeluh karena HP hanya bisa diinstal untuk whatsapp atau mengeluh kuota internet lebih cepat habis dengan mengakses youtube. Hal ini menjadi tantangan Ibu Kristin untuk memanfaatkan teknologi untuk membuat media pembelajaran yang bisa diterima dan mudah diakses setiap murid. Ibu Kristin pun menambahkan, perhatian orang tua sangat penting untuk anak usia SD karena mereka butuh pendampingan belajar. Dan faktanya, hanya ada beberapa murid yang orang tuanya perhatian, selebihnya broken home dan orang tua tidak mempedulikan sistem belajar anaknya. Sehingga banyak murid yang tidak mengumpulkan tugasnya, dan guru menghadapi permasalahan baru untuk memberikan nilai pada murid. Pembelajaran jarak jauh dianggap 
gagal jika tidak terjadi komunikasi dua arah, atau tidak adanya kerjasama antara guru dan murid.

Berbeda yang dialami oleh Ibu Anik, guru Bahasa Inggris di SMP Negeri 1 Tulungagung. Ibu Anik Purwani mengaku tidak ada kendala dalam proses pembelajaran. Ibu Anik Purwani menggunakan google classroom dan fitur video conference dengan google meet. Tidak ada alasan bagi siswa untuk tidak mengikuti pembelajaran, karena SMP Negeri 1 Tulungagung menyediakan pinjam device berupa tablet. Untuk kuota internet, sebelum dapat bantuan dari pemerintah, sekolah juga sudah memberikan bantuan bagi siswa yang kurang mampu.

Guru dituntut untuk melek teknologi tanpa terkecuali, banyak hal-hal baru yang dipelajari dan memerlukan penyesuaian. Untuk pembelajaran anak usia SMP, bahan ajar berupa video lebih menarik dan lebih mudah dicerna karena dilengkapi visual. Menurut Ibu Nanik, minat baca anak usia SMP memang masih kurang. Jika hanya diberi bahan ajar dengan meminta siswanya membaca buku, pembelajaran tidak akan berhasil. Inovasi guru menjadi hal yang krusial, yang awalnya menjelaskan di depan kelas dengan menuliskan materi belajar di papan tulis harus diubah dalam bentuk dalam bentuk video dan mengandalkan akses internet. Platform youtube yang banyak diakses para murid, membuat para guru membuat channel pembelajaran. Guru melakukan recording, editing dan mengunggahnya di youtube, lalu membagikan link videonya di group whatsapp kelas.

Sedangkan yang dialami Ibu Citra Devi, guru di SMA Negeri 1 Kauman, Tulungagung, mengatakan sebagian besar muridnya bisa mengikuti pembelajaran dengan baik dan lebih kondusif. Semua muridnya dipastikan memiliki HP karena para guru memberikan bantuan bagi siswa yang kurang mampu secara swadaya, dan pihak sekolah juga memberikan bantuan kuota internet sebelum mendapatkan bantuan dari pemerintah. Menurut Ibu Citra Dewi selaku guru sejarah, materi yang disampaikan kurang terserap dengan baik karena tidak secara langsung. Banyak muridnya yang akhirnya kurang paham terhadap materi, sehingga butuh pendekatan secara personal kepada murid-muridnya agar mereka bisa mengikuti pembelajaran dengan baik. Ibu Citra tidak mengalami kesulitan dalam menyiapkan bahan ajar. Cukup membuat slide dalam bentuk power point dan mencari materi video yang relevan dari youtube. Karena siswa usia SMA sudah dituntut untuk belajar mandiri dan sudah melek teknologi, guru lebih mudah membagikan bahan ajar dalam bentuk pdf, link website dan link channel youtube.

Bapak Titis Eswindro selaku guru di SMA Negeri 1 Kedungwaru, kendala yang dialami dalam pembelajaran daring adalah memantau respon masing-masing siswa untuk mengetahui kesulitan yang dihadapi. Media pembelajaran yang digunakan Bapak Titis Eswindro cukup beragam, diantanya menggunakan moodle yaitu platform yang bersifat webbased (seluruh kegiatan belajar mengajar dilakukan dengan mengakses website menggunakan browser), unit kegiatan belajar mandiri, video pembelajaran yang diunggah di youtube, media diskusi melalui google classroom dan whatsapp group, pembelajaran video conference melalui zoom dan google meet. Dalam membuat bahan ajar, Bapak Titis Eswindro berinovatif membuat video pembelajaran yang diunggah di youtube, siswa dengan fleksibel dapat mengakses materi pembelajarannya. 
Tabel 2 Ketersediaan Alat Pembelajaran dan Akses Internet

\begin{tabular}{|l|l|l|}
\hline \multicolumn{1}{|c|}{ Nama Sekolah } & \multicolumn{1}{c|}{ Alat Pembelajaran } & \multicolumn{1}{c|}{ Akses Internet } \\
\hline SD Negeri Kauman & $\begin{array}{l}\text { Tidak semua siswa memiliki } \\
\text { HP sendiri. }\end{array}$ & $\begin{array}{l}\text { Kuota internet dari bantuan } \\
\text { pemerintah. }\end{array}$ \\
\hline $\begin{array}{l}\text { SMP Negeri 1 } \\
\text { Tulungagung }\end{array}$ & $\begin{array}{l}\text { Setiap siswa memiliki } \\
\text { HP/Laptop sendiri, dan } \\
\text { sekolah menyediakan } \\
\text { pinjaman device } \text { berupa tablet. }\end{array}$ & $\begin{array}{l}\text { Kuota internet dari bantuan sekolah } \\
\text { dan pemerintah. }\end{array}$ \\
\hline $\begin{array}{l}\text { SMA Negeri 1 } \\
\text { Kedungwaru }\end{array}$ & $\begin{array}{l}\text { Setiap siswa memiliki } \\
\text { HP/Laptop sendiri, dan } \\
\text { sekolah menyediakan } \\
\text { pinjaman HP. }\end{array}$ & $\begin{array}{l}\text { Kuota internet dari bantuan sekolah } \\
\text { dan pemerintah. }\end{array}$ \\
\hline SMA Negeri 1 Kauman & $\begin{array}{l}\text { Setiap siswa memiliki } \\
\text { HP/Laptop sendiri. Bagi yang } \\
\text { kurang mampu, guru } \\
\text { memberikan bantuan HP } \\
\text { secara swadaya. }\end{array}$ & $\begin{array}{l}\text { Kuota internet dari bantuan sekolah } \\
\text { dan pemerintah. }\end{array}$ \\
\hline
\end{tabular}

Sumber: Data diolah peneliti (2021)

Berdasarkan wawancara kepada empat guru di sekolah negeri Tulungagung, akses internet tidak menjadi kendala. Sebelum ada bantuan kuota internet dari pemerintah, pihak sekolah juga memberikan bantuan kuota. Sedangkan untuk alat pembelajaran berupa device handphone atau laptop, pihak sekolah ada yang meminjamkan bagi siswa yang tidak memiliki. Bahkan guru pun secara swadaya turut membantu membelikan handphone bagi siswa yang kurang mampu. Semua berkolaborasi untuk kelancaran PJJ.

Situasi Covid-19 tidak hanya membutuhkan pengetahuan dan keterampilan tetapi juga kepercayaan diri tentang kesuksesan dalam pengajaran online. Oleh karena itu, berkenaan dengan bidang motivasi-afektif fokus pada self-efficacy guru sebagai salah satu konstruksi terpenting dalam kompetensi guru (Lauermann dan König 2016). Berdasarkan karya Bandura (1997), self-efficacy guru menunjukkan keyakinan guru tentang kemampuan mereka untuk berhasil dalam situasi tertentu. Sejauh mana dianggap efektif bagi guru dalam mempengaruhi mereka untuk mengambil tindakan atau tidak, dan berapa lama mereka dapat mempertahankan berbagai tantangan (Tschannen-Moran dan Hoy 2001). Oleh karena itu dengan menganggap peran guru sebagai sumber daya yang menentukan, bagi guru wajib beradaptasi dengan pengajaran online selama penutupan sekolah karena Covid-19 untuk tujuan pembelajaran yang efektif.

Dari berbagai aliran pemikiran, teori konstruktivis kognitif dan teori konstruktivis sosial dapat dianggap sebagai landasan pembelajaran yang efektif. Teori konstruktivis mengakui peserta didik sebagai individu yang aktif. Pelajar adalah pusatnya pembelajaran dan guru berperan sebagai fasilitator dan konselor. Pelajar seharusnya terbuka untuk membentuk pengetahuan sendiri daripada memperolehnya melalui pendidikan. Dalam konstruktivisme, guru percaya pada program pendidikan yang kooperatif dan kelompok belajar dalam memperkuat pembelajaran aktif pada peserta didik. Di dalam pembelajaran aktif, tentunya ada kerjasama dan bekerja dalam kelompok yang merupakan fitur penting dari pembelajaran melalui teknologi (Farajollahi, 2012).

Program dari pemerintah yang berjalan untuk mendukung guru dan tenaga di bidang pendidikan adalah Program Sekolah Penggerak dan Program Pendidikan Profesi Guru, yang dilakukan secara daring. Pemerintah juga memberikan tunjangan profesi guru tanpa harus 
tatap muka, kemudian kebijakan penggunaan dana Bantuan Operasional Sekolah (BOS) dan mendukung secara teknis gerakan guru untuk pelaksanaan pembelajaran jarak jauh (Kemdikbud, 2020).

\section{Media Pembelajaran dalam Pembelajaran Jarak Jauh}

Dalam keberhasilan PJJ, terutama saat online, siapa pun yang memiliki koneksi internet dan perangkat yang mengakses internet dapat berpartisipasi (Jaggars, 2014). Sayangnya, tidak semudah itu. Pertama, koneksi internet dan perangkat yang berfungsi sulit diakses oleh 33 juta orang Amerika dan miliaran di seluruh dunia (Pew Research Center, 2019). Di Indonesia, menurut data kemdikbud (2020) masih ada murid atau peserta didik yang memiliki hambatan pembelajaran jarak jauh yaitu ketidaktersediaan listrik, tidak memiliki laptop atau smartphone, dan ketidaktersediaan internet. Yaitu sebanyak 15\% tersedia listrik namun tidak tersedia internet, dan sebanyak 3\% tidak tersedia listrik.

Pembelajaran jarak jauh tidak hanya berbeda di tempat yang berbeda bagi guru dan siswa, tetapi juga memiliki sistem dan metode yang berbeda. Diperlukan perencanaan, desain, persiapan material, dan komunikasi baru. Guru dan lembaga pendidikan harus mengembangkan dan menggunakan metode dan pembelajaran baru, dari instruksi langsung hingga mengelola strategi pembelajaran, memberikan dukungan kepada siswa, memfasilitasi diskusi jarak jauh dan kebutuhan pribadi (seperti fasilitas dan aksesibilitas). Metode PJJ dilaksanakan melalui sistem e-learning yang erat kaitannya dengan media.

E-learning adalah jenis pembelajaran online yang sangat bergantung pada internet. Dibandingkan dengan metode lain, pembelajaran online terasa lebih tepat dan efektif. Namun, siswa dan guru harus dapat mengakses internet, perangkat seperti laptop atau smartphone, alat atau aplikasi online seperti chat room (ruang komunikasi), atau konferensi video seperti Zoom dan Google Meet. Atau bisa juga aplikasi lain yang bisa menyimpan video dan bisa ditonton siswa kapan saja, seperti Youtube.

Teknologi yang digunakan untuk sistem e-learning sebenarnya bukan sesuatu yang baru, melainkan ada perubahan pemanfaatan teknologi. Konferensi video seperti Zoom dan Google Meet biasa digunakan para pekerja untuk meeting online dengan rekan yang berada di luar daerah atau di luar negeri. Tetapi karena Covid-19, pendidikan memanfaatkan teknologi konferensi video untuk pembelajaran online. Guru, siswa, dan orang tua dituntut untuk beradaptasi terhadap pemanfaatan teknologi. Keberhasilan e-learning tentunya tidak akan berhasil tanpa akses internet yang stabil dan kepemilikan alat seperti smartphone atau laptop.

Semuanya saling berkesinambungan agar PJJ terlaksana dengan baik. Namun jika melihat sisi demografis dan faktor ekonomi di Indonesia, pelaksanaan PJJ mempunyai tantangan yang berbeda-beda. Jika sekolah sudah didukung fasilitas yang memadai dan guruguru yang melek teknologi, tentu bukan tantangan yang besar dalam pembelajaran jarak jauh. Berbeda dengan sekolah-sekolah yang minim fasilitas, seperti tidak ada perangkat komputer, jaringan internet tidak stabil bahkan banyak guru-guru yang kurang melek teknologi. Selain itu, setiap siswa belum tentu memiliki smartphone dan komputer pribadi, sebagian dari mereka masih menggunakan punya orang tua secara bergantian. Disaat akan digunakan orang tua untuk bekerja, maka siswa tidak memiliki perangkat tersebut untuk pembelajaran. 
Kualitas PJJ harus terus dibenahi, pemerataan akses internet yang menjadi sangat krusial dibutuhkan kerjasama sistemik dari pihak pemerintah.

\section{SIMPULAN}

Peran guru sangat menentukan untuk keberhasilan PJJ. Guru-guru di sekolah negeri Tulungagung, beradaptasi dan memanfaatkan teknologi untuk pengajaran berbasis online. Media pembelajaran yang digunakan cukup beragam, yaitu moodle - platform yang bersifat web-based (seluruh kegiatan belajar mengajar dilakukan dengan mengakses website menggunakan browser), unit kegiatan belajar mandiri, video pembelajaran yang diunggah di youtube, media diskusi melalui google classroom dan whatsapp group, pembelajaran video conference melalui zoom dan google meet. Bahan ajar yang dibuat guru, disajikan semenarik mungkin untuk membuat siswa tidak merasa bosan saat belajar.

Alat pendukung untuk pembelajaran menggunakan smartphone atau laptop tidak menjadi kendala untuk tingkat SMP dan SMA. Namun masih ada kendala untuk tingkat SD karena belum memiliki smartphone atau laptop sendiri, pendampingan orang tua sangat menentukan keberhasilan PJJ. Sedangkan untuk akses internet, mendapatkan bantuan kuota internet dari sekolah maupun pemerintah.

Teknologi yang dimanfaatkan sebagai media PJJ tidak menentukan tindakan manusia, tetapi sebaliknya tindakan manusia membentuk pemanfaatan teknologi. Penggunaan video conference yang awalnya digunakan untuk meeting online di kalangan pekerja, semenjak Covid-19 ada perubahan pemanfaatan teknologi untuk keberlangsungan pendidikan di Indonesia. Begitu juga teknologi berbasis chat seperti whatsapp, dimanfaatkan untuk membentuk group kelas dan pemberian tugas mata pelajaran. Bahkan youtube dimanfaatkan menjadi media pembelajaran yang efektif, guru tidak hanya sebagai penonton, melainkan bisa menjadi creator dengan menggunggah video pembelajaran di youtube.

\section{UCAPAN TERIMA KASIH}

Penulis mengucapkan terima kasih kepada para guru di Tulungagung, Jawa Timur yang telah bersedia menjadi nara sumber dalam rangka penelitian ini. Penulis juga mengucapkan terima kasih kepada dosen mata kuliah Teknologi Komunikasi dan Perubahan Perilaku, Program Studi Ilmu Komunikasi, Universitas Negeri Padjadjaran. Ucapan terima kasih juga kepada reviewer dan editor yang telah memberikan saran perbaikan untuk menjadikan artikel ini lebih baik.

\section{DAFTAR PUSTAKA}

\section{Buku dan Jurnal}

Baalen, P. v., Fenema, P. v., \& Loebbecke, C. (2016). Extending the Social Construction of Technology Framework to the Digital World. International Conference Information Systems. Dublin: University of Amsterdam.

Bandura, A. (1997). Self Efficacy: The Exercise of Control. New York: Freeman.

Barbour, M. K., \& Reeves, T. C. (2009). The Reality Of Virtual Schools: A Review Of The Literature. Computers \& Education, 52(2), 402-416. https://doi.org/10.1016/j.compedu.2008.09.009 
Boettcher, J. (2007). Ten Core Principles for Designing Effective Learning Environments: Insights from Brain Research and Pedagogical Theory. Innovate Journal of Online education, vol3, issue3, available: http://www.innovateonline.info/index.php Corona Und Unter Besonderer Berücksichtigung Von Sozialen Ungleichheiten [Learning with

Dewi, N,., Murtinugraha, R. E., \& Arthur, R. (2018). Pengembangan Media pembelajaran Inteaktif Pada Mata Kuliah Teori Dan Praktik Plambing di Program Studi S1 PVKB UNJ. Jurnal pensil, 7(2). 25-34. https://doi.org/10.21009/pensil.7.2.6 Digital Media: Objectives in Times of Corona and under Special Consideration of Social doi:10.2304/elea.2011.8.2.106.

Eickelmann, B., and J. Gerick. 2020. Lernen Mit Digitalen Medien: Zielsetzungen in Zeiten Von US National Educational Technology Plan. E-Learning and Digital Media 8 (2): 106120.

Garrison, R., Terry, A., Walter, A. (2003). A Theory of Critical Inquiry in Online Distance Education. In Handbook of Distance Education, edited by M. Moore and W. Anderson. New Jersey: Lawrence Erlbaum Associates.

Guffey, M. E. (2008). Business Communication: Process \& Product. Mason, OH: Southwestern, Cengage Learning.

Hodges, C., Moore, S., Lockee, B., Trust, T., \& Bond, A. (2020). The difference between emergency remote teaching and online learning. EDUCAUSE Review. https://er.educause.edu/articles/2020/3/the-difference-between-emergency-remoteteaching-and-online-learning

Huber, S. G., and C. Helm. (2020). COVID-19 and Schooling: Evaluation, Assessment and Accountability in Times of Crises-reacting Quickly to Explore Key Issues for Policy, Practice and Research with the School Barometer. Educational Assessment, Evaluation and Accountability 1-34. doi:10.1007/s11092-020-09322-yin Germany. European Journal of Teacher Education Inequities]." Die Deutsche Schule 16: 153-162. doi:10.31244/9783830992318.09.

Jaggars, S. S. (2014). Democratization of education for whom? Online learning and educational. Johannes König , Daniela J. Jäger-Biela \& Nina Glutsch (2020) Adapting to online teaching during COVID-19 school closure: teacher education and teacher competence effects among early career teachers in Germany. European Journal of Teacher Education

Khan, B. H. (2005). Managing E-Learning Strategies: Design, Delivery, Implementation, And Evaluation. Information Science Publishing (an imprint of idea group), Covent Garden, London.

König J, Daniela J. Jäger-Biela \& Nina Glutsch. (2020). Adapting To Online Teaching During COVID-19 School Closure: Teacher Education And Teacher Competence Effects Among Early Career Teachers In Germany. European Journal of Teacher Education Volume 43, 2020

Kozma, R. B. (2011). ICT, Education Transformation, and Economic Development: An Analysis of the US National Educational Technology Plan. E-Learning and Digital Media Volume 8, Number 2, 2011 ISSN 2042-7530

Layne, M., Boston, W. E., \& Ice, P. (2013). A longitudinal study of online learners: Shoppers, swirlers, stoppers, and succeeders as a function of demographic characteristics. Online Journal of Distance Learning Administration, 16(2), 1-12. https://www.westga.edu/ distance/ojdla/summer162/layne_boston_ice162.html 
Lentell, H. (2003). The importance of the tutor in open and distance learning. In A. Tait \& R. Mills (Eds.), Rethinking student support in distance education change and continuity in an international context. London, UK: Routledge Falmer.

Mehran Farajollahi and Nahid Zarifsanaee. (2012). Distance Teaching and Learning in Higher Education: A Conceptual Model. Online journal: cdn.intechopen.com

Mei, L., Su L.W., Ahmad, F. A., \& Rosnaini, M. (2017). Teachers' perceptions of e-learning in Malaysian secondary schools. Malaysian Online Journal of Educational Technology, 5(2) 20-33.

Moore, Michael. (1983). A Theory of Apartness and Autonomy dalam Keegan, Desmond Six Distance Education Theorist. ZIFF: Hagen.

Munawaroh, Isniatun (2005) Virtual Learning dalam Pembelajaran Jarak Jauh. Majalah Ilmiah Pembelajaran No.2, Vol.1 Oktober

Nuriana, I., \& Adelina, F. (2021). Persepsi Orang Tua Terhadap Pembelajaran Jarak Jauh (PJJ). Tanggap: Jurnal Riset dan Inovasi Pendidikan Dasar, 1(2), 83-90

Rahmaati, F. (2016). E-lerning implementasion: Its opportunities and Drawbacks Perceived By EFL Students. Journal of fourign language teaching and lerning, 1(1). https://doi.org10.18196/ftl.111

Rajasegeran, R. (2012). Blended discrete trial clinical method to enhance performance in elearning mathematics courses(B7). Conference proceeding of Smart innovations in Education and lifelong learning. Muang Thong Thani, Nonthaburi, Thailand.

Sa'don, N. F. B., Dahlan, H. B. M., \& Zainal, H. B. (2013, November). Derivation for design of virtual learning environment (VLE) framework for Malaysian schools. Conference proceeding of International Conference on Research and Innovation in Information Systems (ICRIIS; pp. 570-575). IEEE.

Singh, H. (2003). Building Effective Blended Learning Programs. Educational Technology, 44(1), 51-54.

Sugiyono. (2017). Metode Penelitian Kombinasi. Alfabeta, Bandung.

Taylor, D. (2006). Issues, trends, and challenges in distance education: An international perspective. e- Journal of Instructional Science and Technology, 4(1), 41-25.

Tschannen-Moran, M., and A. W. Hoy. 2001. Teacher Efficacy: Capturing an Elusive Construct. Teaching and Teacher Education 17 (7): 783-805. doi:10.1016/S0742-051X(01)00036-1.

Xu, D., \& Jaggars, S. S. (2014). Performance gaps between online and face-to-face courses: Differences across types of students and academic subject areas. The Journal of Higher Education, 85(5), 633-659. https://doi.org/10.1353/jhe.2014.0028

\section{Artikel Online}

Covid19.go.id. (2021). Analisis Data Covid 19 Indonoesia Update 28 Maret 2021. Diakses pada 20 Mei 2021, dari https://covid19.go.id/p/berita/analisis-data-Covid-19-indonesia-update28-maret-2021

Sindo News. (2020). Pandemi Covid-19 Pemerintah Tidak Potong Anggaran Pendidikan. Diakses pada 10 Mei 2021. https://edukasi.sindonews.com/read/21175/144/pandemiCovid-19-pemerintah-tidak-potong-anggaran pendidikan-1588910718 